\title{
Improving Students' English Speaking Skill By Using Their Speaking Video Recording
}

\author{
Suadi $^{1}$ \\ ${ }^{1}$ Corresponding author, Sekolah Tinggi Agama Islam Negeri Mandailing Natal; \\ massuadi14@gmail.com
}

\begin{abstract}
The background of the study was the phenomenon of the first semester students of class A English Language Education Department at STAIN Mandailing Natal. Most of them were seldom using English in everyday activity because they did not have enough motivation, adequate vocabulary, and self-confidence. To activate their speaking skill ability, it was used their speaking video recording. By this, they did not only speak, but also involved in correcting, commenting and evaluating their performance in speaking skill. It was productive solution to overcome their problem. The respondents of this study were 15 first semester students Class A English language Education department in STAIN Mandailing Natal. This study was categorized into Class Action Research (CAR). The method of data collection used in this study was form test of speaking video recording which was measuring seven aspects of speaking skill, they were (1) pronunciation, (2) fluency, (3) word choice, (4) structure, (5) self-confidence, (6) teamwork and (7) creativity. The result of cycle 1 showed that the students' average score in speaking skill was 7.2. In the cycle 2, the students achieved far better average score namely 8.4. It means there was a progress on students' speaking skill achievement after learning through speaking video recording. The conclusion was the use of speaking video recording was able to improve the students' speaking ability because they were brave, motivated and interested to express English as the way they wanted it.
\end{abstract}

Keywords: speaking skill, speaking video recording, class action research

\section{Introduction}

\subsection{Background of the Study}

Speaking is one of four main skills that are obliged to be mastered by the students, most importantly for English department students. Without mastering speaking skill, the message in a communication will not be delivered well. In the context of English language, speaking skill for the English Foreign Learners (EFL Students) is very crucial, mainly for the university students. Luhman (in Kurniati, 2016: 33) emphasized that communication covers many components, namely message, information and understanding. Communication runs well in the condition when the message and information are understood. Based on Luhman's definition, it can be concluded that speaking skill in communication plays a vital role which 
determine the success of communication itself between the speaker and listener. Speaking skill ensures whether the message and information delivered well or not.

When a person speaks, he/she actually does not only utter something letter by letter only, but also delivers a message or information. All senses such as sight, hearing, feeling and intelligence are actively participating in the process of communication. These all will be appearing in the mimic, body language, word choice, pronunciation, fluency, selfconfidence, and creativity of speaker when he/she speaks. Therefore English speaking skill is very significant to steer the students' future. The reason is English nowadays widely most used in spoken way. Without having an adequate English speaking skill, student will be passive and marginalized both domestic and international opportunities.

Wallace (1991: 201) stated that the main goal when the students are learning a foreign language is being able to speak it. In this context, students of English department are obliged to be able to speak English. The students are not only able to speak with it, but also they understand the meaning and able to get the message and information in the communication and conversely she/he is able to give feedback to the speaking partner. To improve students' English speaking skill, it needs creative and innovative approach. Widyawan and Hartati (2016: 26) stated the modern teaching approaches generally focus on students oriented, not material oriented. To make students as the central of English language learning, the educator must facilitate the appropriate approach. One of prospective approaches to be implemented to improve students' speaking skill is by using video. Video will be attracting their motivation, self-confidence, courage and curiosity.

The use of video is relevant with the condition of students in STAIN Mandailing Natal. The students of the first semester English language education department Class A in STAIN Mandailing Natal, Panyabungan commonly seldom use English in their daily conversation. The frequency of using Bahasa Indonesia and Mandalingnese language is far higher than English. The culture of Mandailingnese people also might make them passive in speaking English. English is taught in conventional way such as giving them vocabulary, teaching them a number of English structure and grammar, then asked them to write some sentences and answer some written quiz. All of those monotonous ways lead the students to be passive in English. As a result, the students will never know the usefulness of English language and they are not interested, brave and motivated to learn English because English learning is not vivid, and not encouraging their enthusiasm. Therefore it is relevant to use video to improve students' English speaking skill because this way put the students into real context of speaking and let them to creatively express English as the way they want it.

\subsection{Research Context}

In this research context, the video here was made by the students themselves. First, they (in a group with free topic) speak English with the same distribution of turn talk. It means, each member of group, gets the same chance of turn talk. Everyone was obliged to speak English. Second, someone else recorded their speaking action. After that, by using multimedia (laptop and in-focus), they watch and evaluate the video together. One group, evaluate other group's speaking video recording which is presented via in-focus in front of the class. The aspects to be evaluated were related to the speaking skills development namely: pronunciation, fluency, word choice, structure, self-confidence, teamwork and creativity. 


\subsection{Literary Review}

Speaking is one of four main language skills, namely (1) speaking, (2) listening, (3) reading, and (4) writing. Richard (1994: 1) stated that most people assumed that speaking is central skill. It is realized by human being in natural speech/natural communication through face to face and real time and drives people to speak with fluency and correct. In addition, Dewi (2016: 7) stated that speaking is productive skill comprising of verbal utterance production which is most paid attention in L1 and L2 because it plays vital role to transfer idea or meaning. But, there is a problem in developing speaking skill. It is lack of practice. No wonder Nuraeni (2018: 132) stated that even though English language has been taught to students since in the secondary level as one of compulsory subjects, but in the reality it is common to see Indonesian students are poor in speaking English.

In this research, speaking skill was evaluated from seven aspects: (1) pronunciation, (2) fluency, (3) word choice, (4) structure, (5) self-confidence, (6) teamwork and (7) creativity.

Pronunciation was evaluated by measuring how well the student pronoun a word correctly. It was clearly detected by listening the students' speaking video recording. Redmon and Vrchot (2007) defined pronunciation as how to say words in ways that are generally accepted and understood by listener. Meanwhile fluency, as Hughes (2002) defined, is an ability to express language in an intelligible, reasonable and accurate way without too much hesitation. To achieve this ability, educator (lecturer) drives the students to speak freely to express their idea with free topic and creativity.

Word choice in this research is aspect how good a student uses appropriate words related to the speaking topic and avoids using the same words repeatedly. It sounds related and connected and not boring. Structure as Thornbury (2005) emphasized at least has spoken grammar's features: (1) clause as the basic unit of construction (in communication), (2) head, body and tail construction, (3) mostly used direct speech, (4) a lot f ellipsis, (5) question tags favoured, (6) effect of performance such as hesitation, repeating, incompletion, syntactic blends and false starts. Self-confidence aspect refers to how brave and how good the quality of being certain on expressing language. Teamwork tends to how each group member build logical and good speaking performance. The last is creativity. This point refers to how creative and how good the quality of performance and quality of video the students made. The quality of the video could be seen from their ability to edit and to add some features like lighting, background and back sound in the video without manipulating the essence of process making of video itself.

The use of video is intended to improve students' speaking skill and at the same time to eliminate speaking obstacles such as shyness because of less self-confidence, fear of making mistake, strong effect of genuine accent of mother tongue, poor speaking practice, lack of vocabularies, poor listening practice, and lack of motivation caused by many aspects namely boredom on learning approach, rigid method and old way of teaching. It is in line with Arianti, Nurnaningsih and Pratiwi (2018: 71) teaching speaking by using video will drive students into new perspective of teaching learning process. Teaching learning process is more fun, interesting and understandable for building up students' speaking ability.

In terms of using video in teaching speaking, there were some studies had been done. Firstly, Dewi (2016) did a research entitled: “Improving Students Speaking Skills By Using Video Clip at Second Grade of Man 1 Bandar Lampung”. Her general research conclusion 
was that there was a significant improvement of the students' speaking skill after teaching them by using video clip. Her study is different with this study in terms of subject of research and type of video. Her by using video clip invented, not independently created by students, in contrast with this recent study that the video was made by students independently. Secondly, Widyawan and Hartati (2016) did a research entitled: "Improving Students' Speaking Skill By Using Their Spoken Audio Recording in the Middle School”. Their general research conclusion was the spoken audio recording made by students effectively could improve students' speaking skills. The difference with this current study is, their research got students to make independently spoken audio recording, meanwhile this study gets the students to make independently a speaking video recording.

\subsection{Research Objective}

This study was expected to prove whether using the students' speaking video recording was giving improvement to students' speaking skill or not. Moreover, this study was expected to be reference for English educator in teaching speaking by using video, especially by using students' speaking video recording. To find out whether or not learning through the students' speaking video recording is improving their speaking skill.

\section{Method}

This type of study was Class Action Research (CAR) which was supported by quantitative data to interpret the result of pre-test and post-test. In the process of research, it consisted of planning, acting, observing and reflecting the problem to improve. In this study the problem to be improved was students' speaking skill. Wallace in Widyawan and Hartati (2016) stated that the action research should result immediately and it should be specific result which has relation with the activities and it can be a good reference for teacher.

This study was conducted in the first semester class of English Language Education Department in Sekolah Tinggi Agama Islam Negeri (STAIN) Mandailing Natal. The main problem was the lack of speaking skill of the students. They were seldom speaking English. There were some aspects affecting them why seldom speaking English such as lack of selfconfidence, fear of making mistake, poor vocabularies and lack of ability to self-assess or self-correct in speaking. In the end, students never know how good or how bad their English speaking skills.

\subsection{Respondents}

The respondents of this study were 15 first semester students of Class A English Language Education Department in STAIN Mandailing Natal.

\subsection{Instruments}

The instrument of collecting data in this study was the form of speaking video recording tests of pre-test cycle 1 and speaking video recording tests of post-test cycle 2 . 


\subsection{Procedures}

Cycle 1, students were asked to make group. Each group consisted of 5 students. From 15 students, there were divided into three groups. Then, they were asked to create video containing their conversation with free topic. After all groups finished their video, they were asked to present in front of the classroom which was supported by in-focus. When the speaking video recording of group 1 was being presented, group 2 and group 3 gave correction, comments and evaluation. Vice versa, when group 2's video was presented, group 1 and group 3 gave correction, comments and evaluation. So did group 3.

Cycle 2, students were asked to remake the speaking video recording with the same previous topic. Then, they were asked to present the video in front of the classroom. When the video of group 1 was being presented, group 2 and group 3 gave their comment, assessment and evaluation. So did group 2 and group 3.

There were seven aspects to be corrected, commented and evaluated, namely: (1) pronunciation, (2) fluency, (3) word choice, (4) structure, (5) self-confidence, (6) teamwork and (7) creativity.

\subsection{Data Analysis}

In data analysis, the students' speaking video recordings were scored. There were seven aspects had been scored, they were: (1) pronunciation, (2) fluency, (3) word choice, (4) structure, (5) self-confidence, (6) teamwork and (7) creativity. The choice of those aspects to be scored since it is relevant with the speaking skill ability. The scoring aspects can be described as follows:

\begin{tabular}{|c|c|c|c|}
\hline No & Aspects & Score & Description \\
\hline \multirow[t]{5}{*}{ I } & Pronunciation & $1-2$ & Total Incomprehensible \\
\hline & & $3-4$ & Many errors, very little comprehensible \\
\hline & & $5-6$ & Accurate pronunciation with many errors \\
\hline & & $7-8$ & Accurate pronunciation with little error \\
\hline & & $9-10$ & Total Accurate pronunciation \\
\hline \multirow[t]{5}{*}{ II } & Fluency & $1-2$ & Full hesitation, long pauses \\
\hline & & $3-4$ & many hesitations and pauses, but continue \\
\hline & & $5-6$ & Continue with hesitations and pauses \\
\hline & & $7-8$ & Natural with a little pause \\
\hline & & $9-10$ & Natural - native speaker like \\
\hline \multirow[t]{5}{*}{ III } & Word choice & $1-2$ & No response \\
\hline & & $3-4$ & Response but inaccurate \\
\hline & & $5-6$ & Many errors, but generally appropriate \\
\hline & & $7-8$ & Correct with little inappropriate \\
\hline & & $9-10$ & Consistency correct during conversation \\
\hline \multirow[t]{5}{*}{ IV } & Structure & $1-2$ & Full errors \\
\hline & & $3-4$ & Many errors \\
\hline & & $5-6$ & Accurate with many errors \\
\hline & & $7-8$ & Accurate, with very little error \\
\hline & & $9-10$ & No error found \\
\hline \multirow[t]{2}{*}{$\mathrm{V}$} & Self-confidence & $1-2$ & Mute \\
\hline & & $3-4$ & Response but dominated by shyness \\
\hline
\end{tabular}




$\begin{array}{lll} & 5-6 & \text { Responses with hesitation } \\ & 7-8 & \text { Natural with little hesitation } \\ & 9-10 & \text { Full self-confidence } \\ \text { VI Teamwork } & 1-2 & \text { Total disconnected } \\ 3-4 & \text { Rather connected } \\ & 5-6 & \text { Connected with many inappropriate } \\ & 7-8 & \text { Connected with slight inappropriate } \\ & 9-10 & \text { Full connected } \\ & 1-2 & \text { Totally not creative } \\ \text { VII Creativity } & 3-4 & \text { Very little creative } \\ & 5-6 & \text { Lack of creative with many improvement } \\ & 7-8 & \text { Creative with recommended improvement } \\ & 9-10 & \text { Full creative }\end{array}$

To simplify the interpreted quantitative data, it was used scoring method. There were two types of scoring in this study. They were: (1) student's score, (2) average score.

\subsubsection{Students' score}

There were seven aspects to be measured. Each aspect reached the score of 10 as the maximum score. The ideal score of total seven aspects were 70. The formula of scoring was as follows:

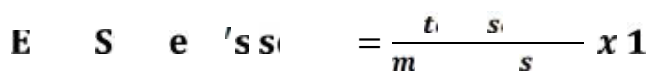

For example: a student got total score of seven aspects was 46.7. Total score 46.7 was gained from seven aspects as follows:

1. Pronunciation $=6.0$

2. Fluency $=6.2$

3. Word choice $=6.5$

4. Structure $=6.3$

5. Self-confidence $=7.0$

6. Teamwork $=7.2$

7. Creativity $=7.5$

It means each student got score of all seven aspects 66.7. It was formulated as follows:

$$
\frac{t_{1} \quad s_{1}}{m} \quad s 1=\frac{4.7}{7} \times 1=6.7
$$

\subsubsection{Average Score}

The average score was measured to determine the improvement of students' speaking skills through speaking video recording. The formula was as follows:

$$
M=\frac{\sum X}{N}
$$




$$
\begin{aligned}
& \mathrm{M}=\text { Average } \\
& \sum \mathrm{x}=\text { total score } \\
& \mathrm{N}=\text { Total students }
\end{aligned}
$$

Example: total students got average score 66. It was gained from the data as follows:

$$
a=\frac{t s}{T S}=\frac{9}{1} \times 100=66
$$

\section{Finding and Discussion}

In this study, the findings were gained through two cycles namely cycle 1 of pre-test and cycle 2 of post-test. Each cycle, students improved their English speaking skills through their speaking video recording. This study was steered based on research question formulated as follows: "is learning through the students' speaking video recording improving their speaking skill?" Based on the data, the comparison between cycle 1 and cycle 2 resulted a significant improvement in students' speaking skill.

Based on the data of cycle 1, the results of total score of students in cycle 1 of pre-test was 107.8 and the average score was 7.2. If it is converted into percentage, it is equivalent to $72 \%$. In contrast to the data of cycle 2 which was the total score of cycle 2 of post-test is 126.2 and the average score is 8.4. If it is converted into percentage, it is equivalent to $84 \%$. The aggregate between cycle 1 of pre-test and cycle 2 of post-test was $12 \%$. It means that the cycle 2 of post-test was higher $12 \%$ than cycle 1 of pre-test.

In the second cycle clearly showed a significant improvement of students' speaking skills than in the first cycle. In the second cycle, the pronunciation was being more accurate with little error, the fluency was being more natural with little pause, the word choice of vocabularies is more consistent and more appropriate with little inappropriate. This is in line with Oladunjoye (2017: 86) with sufficient repetition and practicing the vocabulary, the vocabulary maybe not acquired entirely correctly but more than enough to make the students able to communicate in social situation. Moreover, the data result also showed that the structure was accurate with little errors. In addition, their self-confidence in speaking performance was also being more natural with little pause and even for some was being full self-confidence.

In the speaking video recording of cycle 2, the teamwork of students is raising significantly. The speaking flow was connected with a very slight inappropriate. Their videos were also very creative by adding back sound, subtitle, necessary clipped, and needed sentences. For general conclusion, the students' speaking skill in the cycle 2 of post-test was far better than the cycle 1 of pre-test. The positive achievement in cycle 2 was considered enough, therefore the researcher stopped to give the cycle to the students. They are considered improved and able to express English with good speaking skill. 
These are the results of pre-test of the cycle 1 and post-test of the cycle 2 .

1. Students' average score of pre-test in cycle 1 .

$$
M=\frac{\sum X}{N}=\frac{1.8}{1}=7.2
$$

2. Students' average score of post-test in cycle 2 .

$$
M=\frac{\sum X}{N}=\frac{1.2}{1}=8.4
$$

The progress of the students' speaking skill improvement from cycle 1 to cycle 2 can be seen in the figure below.

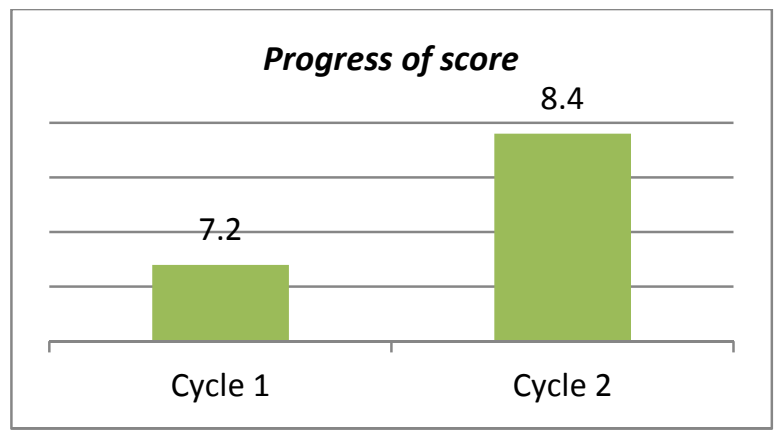

Figure 1. Chart of students' speaking skill average score progress

Based on the above chart, it shows that the teaching and learning process using the students' speaking video recording was effectively used to improve students' speaking skill. The cycle 1 of pre-test showed that the average score of the students was 7.2. It is very different with the cycle 2 of post-test which shows the result 8.4. The progress of students' improvement in percentage clearly appeared as follows.

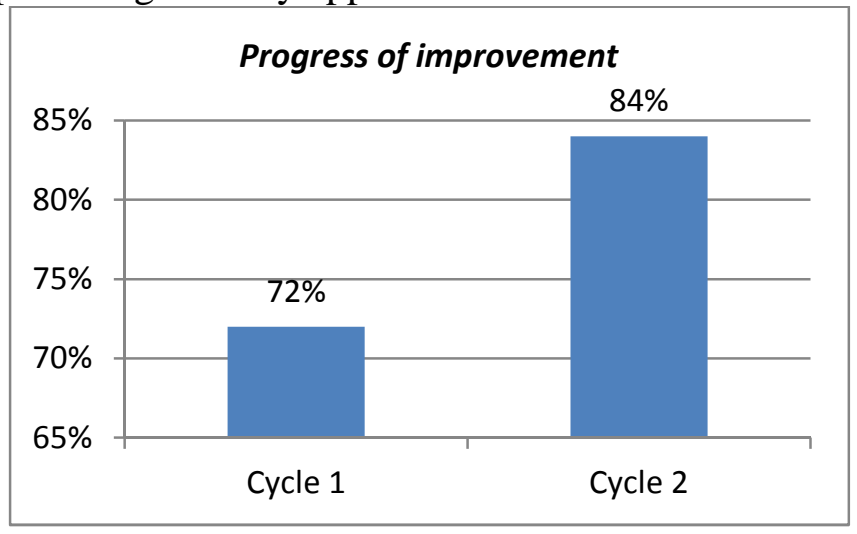

Figure 2. Chart of students' speaking skill improvement progress

From the result of cycle 1 and cycle 2, it is interpreted that learning with speaking video recording can improve students' speaking skill in English. 


\section{Conclusion}

Based on the result of data cycle 1 and cycle 2 in the finding and discussion, it can be concluded as follows. The 15 students of first semester class A English Department STAIN Mandailing Natal faced some obstacles to improve their English speaking skill. The identified obstacles were lake of motivation, poor pronunciation, lack of fluency, having low of vocabulary, error structure, low self-confidence, poor teamwork and low creativity. Second, by using students' speaking video recording, the seven aspects of speaking skill focused in this study were effectively improved namely (1) pronunciation, (2) fluency, (3) word choice, (4) structure, (5) self-confidence, (6) teamwork and (7) creativity.

There was effective improvement in students' speaking skill by using students' speaking video recording. This finding can be alternative media for English educator (lecturer, teacher, tutor) to teach speaking, especially for students of first semester English Department in STAIN Mandailing Natal. The appropriate approach must be student centered which will encourage their interest, motivation, curiosity, and performance. Students made video can be a relevant answer for it in accordance students' involvement in improving their speaking skill.

\section{References}

Arianti, A., Nurnaningsih and Pratiwi, V., U. (2018). A Media for Teaching Speaking Using Youtube Video. Published by Atlantis Press, International Conference on Applied Science and Engineering (ICASE 2018). Advances in Engineering Research, volume 175 page 71.

Dewi, S., F. (2016). Improving Students Speaking Skills By Using Video Clip At Second Grade of Man 1 Bandar Lampung. Universitas Lampung. Skripsi. Unpublished.

Hughes, R. (2002). Teaching and researching speaking. UK: Pearson Education Limited.

Luhman in Kurniati, (2016). The Effectiveness of Animation Video in Teaching Speaking To Junior High School. Journal of English Language and Education, Vol 2. No. 1, June 2016 page 33. ISSN : 2541-6421.

Nuraeni. (2018). Using Audio Visual to Enhance Students' Speaking Skill. Presented in The 65th TEFLIN International Conference, Universitas Negeri Makassar, Indonesia 1214 July 2018. page 132.

Oladunjoye, O., S. (2017). Teaching Vocabulary Using Film and Video: The Development of Senior Secondary Students' Register. International Journal of English Language Teaching. Vol.5, No.2, pp.83-90, February 2017. Online ISSN 20550839.

Redmond, M.V. \& Vrchota, D. (2007). Everyday Public Speaking. England: Pearson Education

Richards, Jack C. (1994). New Ways in Teaching Speaking USA. Pantagraph Printing.

Thornbury, S. (2005). How to teach speaking. England: Pearson Education limited. 
Widyawan, W., K \& Hartati, E. (2016). Improving Students' Speaking Skill By Using Their Spoken Audio Recording In The Middle School. Journal of English Language and Education, Vol 2. No. 1, June 2016 page 26. ISSN : 2541-6421.

Wallace, M.J. (1991). Training foreign Language Teachers. Cambridge: Cambridge University Press. 